\title{
PENGARUH RELIGIUSITAS TERHADAP HARDINESS
}

\author{
Ilmi Amalia \\ UIN Syarif Hidayatullah Jakarta \\ ilmi.amalia@uinjkt.ac.id
}

\begin{abstract}
Concept of hardiness has been developed since 1970s, start from an intensive and longitudinal from Kobasa and Maddi to managers in Illinois Bell Telephone corporation. Since that, the concept of hardiness is one of the concept that support human mental health development. There is yet a research that show the direct relationship between religiousity and hardiness. Indonesian civilian with the majority of muslim, religiousity is the source value within indviduals, so that individuals can develop hardiness within them. This research showed that religousity have a contribution by 15,5\% towards hardiness. Besides that, even though the percentage is low on other variable, is not impossible that the other variable can give a contribution.
\end{abstract}

Keywords: Hardiness, Islam. Religion, Religiousity, Resilience

\begin{abstract}
Abstrak
Konsep mengenai hardiness berkembang sejak tahun 1970an dimulai dari penelitian yang intensif dan longitudinal dari Kobasa dan Maddi (dalam Maddi 2006) pada para manajer di perusahaan Illinois Bell Telephone (IBT). Sejak itu konsep hardiness terus berkembang sebagai salah satu konsep yang mendukung perkembangan kesehatan mental manusia. Belum ada penelitian yang menunjukkan hubungan langsung antara religiusitas dan hardiness. Pada masyarakat Indonesia dengan jumlah muslim yang mayoritas, dimana religiusitas menjadi sumber utama nilai maka sehingga bisa jadi nilai-nilai religiusitas dapat menjadi sumber berkembangnya pribadi hardiness. Hasil penelitian menunjukkan bahwa religiusitas memberikan kontribusi sebanyak 15,5\% terhadap hardiness. Hasil penelitian menunjukkan bahwa hardiness dan religiusitas berbagi varians yang sama namun angka persentase yang kecil menunjukkan bisa jadi ada variabel-variabel lain yang memberikan kontribusi.
\end{abstract}

Kata Kunci: Hardiness, Religiusitas, Resiliensi, Islam, Agama 


\section{PENDAHULUAN}

Konsep mengenai hardiness berkembang sejak tahun 1970an dimulai dari penelitian yang intensif dan longitudinal dari Kobasa dan Maddi (dalam Maddi 2006) pada para manajer di perusahaan Illinois Bell Telephone (IBT). Sejak itu konsep hardiness terus berkembang sebagai salah satu konsep yang mendukung perkembangan kesehatan mental manusia. Konsep hardiness adalah konsep yang cukup relevan diterapkan di Indonesia sebagai negara yang masyarakatnya memiliki banyak stressor. Indonesia adalah negara negara yang rawan bencana alam mulai dari gempa bumi, banjir, tanah longsor, dan sebagainya. Selain itu, Indonesia juga negara yang rawan bencana social mengingat kondisi ekonomi, social, dan politik yang tidak terlalu stabil. Kondisi itu tentu menuntut manusia Indonesia untuk menjadi pribadi yang tangguh.

Hardiness dideskripsikan oleh Kobasa (dalam Maddi, 2006) sebagai gaya atau pola kepribadian yang terkait dengan kesehatan dan performa dibawah stres. Seseorang yang hardy memiliki komitmen kerja, memiliki perasaan bahwa apapun yang terjadi berada dibawah control orang tersebut, dan terbuka terhadap perubahan dan tantangan dalam hidup. Mereka cenderung menginterpretasikan kejadian yang menekan dalam hidup sebagai sesuatu hal yang menarik untuk dihadapi. Secara singkat kepribadian hardiness ditandai denga tiga $\mathrm{C}$ yaitu commitment, control, dan challenge.

Beberapa penelitian menunjukkan bahwa hardiness membantu dalam meningkatkan atau mempertahankan performa dan kesehatan ketika berada dalam kondisi stress. Penelitian ini dilakukan dalam berbagai jenis pekerjaan dan kondisi hidup (Maddi, 2006). Studi Bartone (dalam Maddi 1999) tentang efek penempatan tugas militer menggabungkan tekanan keluarga, gangguan dan kejutan budaya dengan bahaya fisik yang dihadapi. Sekali lagi, sikap hardy diukur sebelum penempatan menjadi buffer dalam hubungan stres-penyakit. Kemudian penelitian lebih lanjut oleh Maddi (1999) menunjukkan bahwa sikap hardiness berhubungan dengan gaya coping stress tranformasional dan berkorelasi negative dengan gaya coping stress regresi.

Studi analisis komparatif menunjukkan bahwa hardiness memiliki kontribusi paling besar dibandingkan dengan rasa optimis dalam mengatasi stres akibat penyakit kanker. Penelitian yang lain juga menunjukkan bahwa hardiness memiliki kontribusi yang lebih besar dibandingkan religiusitas dalam mengatasi depresi dan kemarahan pada perwira militer. Secara teoritis, menurut Maddi (2006) religiusitas dan hardiness adalah konsep yang saling berkaitan namun hubungannya tidak terlalu kuat. Religiusitas dapat melemahkan hardiness seseorang karena terlalu bergantung kepada Tuhan, ketergantungan pada Tuhan dapat melemahkan keyakinan seseorang dalam mengatasi masalah. Konsep ini dibuat berdasarkan tataran social budaya 
Barat yang tentu saja bertentangan dengan dunia Timur yang menempatkan agama sebagai sumber kebaikan yang utama.

Beberapa penelitian menunjukkan bahwa religiusitas memiliki kaitan dengan resiliensi. Menurut Kumpfer (1999), salah satu kelompok factor internal yang mempengaruhi resiliensi adalah karakteristik motivasi atau spiritual. Karakteristik ini menggambarkan kemampuan kognitif atau system kepercayaan yang memotivasi individu dan menciptakan tujuan hidup. Beberapa ciri spiritual yang membuat individu bertahan setelah mengalami tekanan hidup adalah kemampuan untuk menciptakan misi atau tujuan dalam hidup, keyakinan bahwa keberadaan indivudu dalam dunia memiliki tujuan kosmik yang unik, dan keinginan membantu orang lain (Kumpfer,1999). Ciri-ciri spiritual tersebut dapat ditemukan dalam agama.

Selain itu, Pargament dkk memperkenalkan bagaimana religiusitas mempengaruhi cara mengatasi stres (dalam Faigin dan Pargament, 2011). Pargament (dalam Pargament 2011) menjelaskan bahwa positive religious coping sebagai cara untuk menginterpretasikan dan berespon terhadap permasalahan hidup yang merefleksikan hubungan dengan Tuhan, makna dan tujuan hidup, hubungan spiritual dengan orang lain, dan pertolongan Tuhan. Ano dan Vasconcelles (2005) dalam studi metanalisis menyimpulkan bahwa positive religious coping memiliki kaitan yang positif dengan adaptasi terhadap stressor. Religiusitas juga bisa berfungsi sebagai perantara menuju sumber resiliensi yang lain. Beberapa hal yang menjadi sumber resiliensi yaitu tingkat kecerdasan yang tinggi, memiliki harapan atau optimis, emosi positif, dan sanak saudara yang menyayangi serta melindungi (Goldstein dan Brooks, 2005).

Walaupun demikian, pemaparan di atas belum menunjukkan hubungan langsung antara religiusitas dan hardiness. Pada masyarakat Indonesia dengan jumlah muslim yang mayoritas, dimana religiusitas menjadi sumber utama nilai maka sehingga bisa jadi nilai-nilai religiusitas dapat menjadi sumber berkembangnya pribadi hardiness. Oleh karena itu, dalam penelitian ini, peneliti ingin mengetahui seberapa besar kontribusi religiusitas terhadap berkembangnya sikap hardiness. Tujuan penelitian ini adalah untuk melihat bagaimana pengaruh religiusitas terhadap sikap hardiness.

\section{METODE}

Dalam rangka menjawab pertanyaan penelitian yaitu bagaimana pengaruh religiusitas terhadap hardiness peneliti mengunakan model statistika, karena datanya berupa angka - angka yang merupakan hasil pengukuran atau perhitungan. Dalam hal ini, berdasarkan hipotesis yang akan diukur peneliti menggunakan teknik analisis multiple regression atau analisis regresi berganda untuk mengetahui besar dan arah hubungan antara independen variabel dengan dependen variabel. Untuk uji validitasnya peneliti menggunakan 
confirmatory factor analysis (CFA) dengan program LISREL 8.7 (Linear Structural Relationship). Subjek pada penelitian ini adalah mahasiswa Universitas Islam Negeri Syarif Hidayatullah Jakarta berjumlah 208 orang.

Untuk pengembangan instrument maka peneliti mendefinisikan hardiness sebagai gaya kepribadian yang ditandai dengan tiga aspek yaitu commitment, control, dan challenge. Individu yang memiliki tingkat commitment tinggi adalah ketika menghadapi stressor ia dengan sepenuhnya akan menghadapi situasi maupun orang-orang yan terlibat di dalamnya. Individu yang memiliki tingkat control yang tinggi akan menyakini bahwa setiap keluaran yang ada berasal dari perbuatannya sehingga ia akan berusaha untuk berbuat sesuatu. Individu yang memiliki tingkat challenge yang tinggi adalah ia akan melihat masalah sebagai kesempatan untuk belajar mengembangkan diri.

Untuk mengukur tingkat Hardiness, peneliti menggunakan Dispositional Resilience Scale (DRS-15) yang dikembangkan oleh Bartone (1995). Skala ini terdiri dari 15 item dan subjek menjawab dengan cara memilih pilihan jawaban tidak setuju, kurang setuju, setuju, atau sangat setuju. Setiap jawaban memiliki skor yang berbeda, pada pernyataan positif jawaban tidak setuju diberi nilai 1 , kurang setuju diberi nilai 2 , setuju diberi nilai 3, dan sangat setuju diberi nilai 4. Untuk pernyataan negative, penilaiaannya berkebalikan dengan pernyataan positif. Skor subjek didapat dengan menjumlahkan pilihan jawabannya. Hasil uji validitas dengan menggunakan confimatory factor analysis menunjukkan ada empat item yang tidak valid yaitu item 5 , item 7 , item 11 dan item 15 , sedangkan sisa item lainnya dinyatakan valid. Dengan demikian keempat item tersebut tidak diikutsertakan dalam pengolahan data berikutnya.

Religiusitas yang dibahas dalam penelitian ini adalah religiusitas Islam. Religiusitas Islam didefinisikan dengan dua aspek yaitu Islamic Worldview dan Religion Personality. Islamic Worldview menggambarkan ajaran tauhid merefleksikan tauhid berdasarkan Rukun Iman. Rukun Iman terdiri keyakinan akan adanya Allah SWT, Malaikat, Nabi dan Rosul, Kitab Suci, Hari Kiamat, dan Qada serta Qadar. Religion Personality menggambarkan bagaimana ia berperilaku dan berinteraksi di dunia yang dituntun oleh ajaran Islam serta termotivasi karena Allah SWT. Konstruk ini terdiri dari dua aspek yaitu ibadah yang menggambarkan Rukun Islam dan mu'amalat yang menggambarkan interaksi dengan ciptaan Allah SWT lainnya.

Untuk mengukur religiusitas Islam, peneliti menggunakan Muslim Religiosity Personality Inventory (MRPI) yang dikembangkan oleh Krauss dkk (2009). MRPI terdiri dari dua aspek yaitu Islamic Worldview dan Religios Personality. Islamic Worldview terdiri dari 23 item dengan 13 item postif dan 10 item negative. Subjek menjawab dengan memilih pilihan jawaban sangat setuju, tidak setuju, ragu-ragu, setuju, atau sangat setuju. Setiap jawaban memiliki skor yang berbeda, untuk pernyataan positif jawaban sangat setuju diberi skor 5 , setuju diberi skor 4 , ragu-ragu diberi 
skor 3, tidak setuju diberi skor 2, dan sangat tidak setuju diberi skor 1 . Pernyataan negative diberi nilai berkebalikan dengan pernyataan positif. Religious Personality terdiri dari dua konstruk yaitu ibadah dan muamalah. Item yang menggambarkan ibadah dan muamalah masing-masing terdiri dari 16 item. Semua pernyataan merupakan kalimat positif. Subjek mejawab dengan memilih pilihan tidak pernah, jarang, kadang-kadang, sering, atau selalu. Setiap jawaban memiliki skor yang berbeda, untuk jawaban tidak pernah diberi skor 1 , jarang diberi skor 2, kadang-kadang diberi skor 3 , sering diberi skor 4 , dan selalu diberi skor 5. Tingkat religiusitas diperoleh dengan menjumlahkan skor pilihan jawaban subjek.

Hasil uji validitas dengan menggunakan confirmatory factor analysis pada skala Islamic World View menunjukkan bahwa dua item tidak valid yaitu item 14 dan item 15, sedangkan sisa item lainnya dinyatakan valid. Kedua item tersebut dinyatakan tidak valid sebab koefisien muatan faktor kedua item tersebut memiliki arah yang negatif. Tentu koefisien item yang negatif bertentangan dengan sifat item yang positif. Oleh sebab itu, kedua item tersebut dibuang pada analisis data selanjutnya. Hasil uji validitas pada skala Religious Personality menunjukkan hanya satu item yang tidak valid yaitu item 19. Hal ini dikarenakan item 19 memiliki nilai $t<1,96$. Oleh sebab itu item 19 tidak digunakan pada pengolahan data lebih lanjut.

\section{HASIL}

Subjek penelitian ini adalah 208 mahasiswa S1 yang berusia antara 17 dan 24 tahun. Rata-rata usia subjek adalah 19,8 tahun $(\mathrm{SD}=2,92)$. Subjek penelitian lebih didominasi jenis kelamin perempuan sebanyak $54,8 \%$. Asal fakultas subjek lebih banyak didominasi dari fakultas psikologi sebanyak $51,9 \%$ dan diikuti fakultas tarbiyah sebanyak $26 \%$.

Masalah utama yang ingin dijawab dalam penelitian ini adalah bagaimana kontribusi religiusitas terhadap hardiness. Hasil pengolahan data menunjukkan bahwa variabel Islamic world view dan religious personality berpengaruh secara signifikan terhadap variabel hardiness $(\mathrm{p}<0.05)$. Religiusitas memberikan kontribusi sebesar 15,5 \% terhadap hardiness. Secara parsial kedua independen variabel tersebut berpengaruh signifikan terhadap hardiness. Koefisien regresi religious personality sebesar $0.582(\mathrm{p}<$ $0.05)$, sedangkan koefisien regresi world view sebesar $1,166(\mathrm{p}<0.05)$. 


\section{DISKUSI}

Hasil penelitian menunjukkan bahwa variabel religiusitas berpengaruh terhadap hardiness. Hal ini sesuai dengan penelitian Maddi, Brow, Khoshaba, dan Vaitkus (2006) yang menunjukkan bahwa terdapat korelasi antara hardiness dan religiusitas. Dapat diartikan bahwa antara hardiness dan religiusitas berbagi varians yang sama yaitu dalam hal spiritual yaitu dalam konteks untuk mencari makna hidup.

Namun demikian kontribusinya tidak terlalu besar hal ini mungkin dikarenakan antara religiusitas dan hardiness terdapat hal yang berbeda yaitu sumber dan arah spritualitasnya. Hardiness berdasarkan filsafat eksistensialisme, yang berarti ketiga aspek commitment, control, dan challenge bersumber dari pergulatan si individu sendiri dalam memaknai peristiwa dan stressor dalam hidupnya. Religiusitas merupakan konsep yang bersumber dari Sang Pencipta, perbedaan terutama terlihat dalam aspek control dan challenge

Dalam aspek control dapat dikatakan bahwa seorang muslim tidak dapat sepenuhnya menguasai perilakunya. Dalam rukun iman dijelaskan bahwa seorang muslim harus percaya terhadap Qodha dan Qadar. Qodha adala segala sesuatu yang direncankan dan ditentukan Allah SWT terhadap mahluknya sedangkan Qadar adalah ketetapan Allah SWT yang terjadi pada diri kita. Hal ini berarti seorang muslim wajib berusaha namun hasil akhir dari usahanya sangat bergantung pada kehendak Allah SWT.

Perbedaan konsep juga terdapat pada aspek challenge. Aspek challenge terkait dengan pergulatan individual dalam memaknai hidup yang berbeda dengan religiusitas dimana makna hidup bersifat dogma dan sudah terberi.

Religiusitas adalah konstruk yang bersifat multi dimensional sehingga bisa jadi alat ukur yang peneliti gunakan tidak mencangkup bentuk-bentuk konstruk yang lain. Fetzer (1999) mengidentifikasi beberapa ranah agama/spiritual yang memiliki pengaruh terhadap kesehatan mental antara lain religiousitas sebagai strategi coping stress, forgiveness, and religious support. Penelitian selanjutnya dapat menambahkan religious support karena masyarakat Indonesia sebagai masyarakat kolektif tidak dapat lepas dari kelompoknya. Religious support mengacu pada dukungan social dalam konteks agama seperti kelompok pengajian dan organisasi social kemasyarakatan berdasarkan agama. Menurut Krause (1999 in fetzer 1999), ada dua cara yang dapat dilakukan religious support untuk meningkatkan kesehatan dan kesejahteraan. Pertama, bantuan dari ummat dapat membantu untuk mengimbangi efek berbahaya dari peristiwa kehidupan yang penuh stres. Kedua, religious support mungkin merupakan penentu penting dari kesehatan dalam hubungan yang langsung (model efek langsung).

Selain itu, hal yang perlu diperhatikan dalam penelitian ini adalah skala religiusitas yang digunakan peneliti. Dalam aspek Religius Personality, 
peneliti menemukan penyebaran skor yang tidak merata (untuk lebih detail dapat melihat Gambar 4.3). Hal ini kemungkinan dalam masyarakat yang religious, subyek penelitian akan cenderung menjawab secara normatif dan tidak menggambarkan keadaan sesungguhnya.

Secara umum dapat dikatakan sangat jarang penelitian yang menempatkan hardiness sebagai variabel dependen, salah satunya penelitian oleh Khoshaba dan Maddi (1999) yang menunjukkan pengaruh keluarga dalam membentuk pribadi yang hardy. Oleh karena itu untuk penelitian selanjutnya dapat menambahkan variabel dependen lainnya seperti peran keluarga atau orangtua.

Penelitian lain yang dilakukan oleh Zhang dan Wong (2011) untuk melihat pengaruh gaya berpikir terhadap hardiness. Gaya berpikir kreatif dan yang membolehkan untuk berkolaborasi dengan orang lain dapat berkontribusi secara positif terhadap hardiness. Penelitian ini dilakukan dalam konteks dunia pendidikan tinggi untuk lebih meningkatkan keberhasilan mahasiswa dalam studinya. Penelitiannya selanjutnya juga dapat menambahkan variabel gaya berpikir.

Hardiness juga dapat diterapkan dalam dunia industry dan organisasi (Maddi, Khosaba, dan Pammenter, 1999). Pada konteks itu tentu banyak factor yang berperan seperti dukungan social dari rekan kerja atau atasan, kepuasan kerja, work benefit, dll. Selain itu, Maddi, Kahn, dan Maddi (1998) juga menyatakan bahwa menjadi pribadi yang hardy dapat dipelajari dengan pelatihan dan pengajaran. Peneltian selanjutkan dapat juga dilaksanakan untuk melihat efektivitas pelatihan hardiness dalam konteks Indonesia.

\section{DAFTAR PUSTAKA}

Abu Raiya, H. (2006). A Psychological Measure Of Islamic Religiousness: Evidence for Relevance, Reliability and Validity. Unpublished doctoral dissertation. Graduate College of Bowling Green State University.

Alwisol. (2008). Psikologi Kepribadian. Malang: UMM Press

Ano, G. G., \& Vasconcelles, E. B. (2005). Religious coping and psychological adjustment to stress: A meta-analysis. Journal of Clinical Psychology, 61, 461-480. doi: 10.1002/jclp.20049

Bartone, P. T., (1995). A Short Hardiness Scale. Paper presented at The Third Annual Convention of The Association Psychological Society. Washington DC.

Faigin, C. A., \& Pargament, K. I. (2011). Strengthened by the Spirit: Religion, Spirituality, and Resilience Through Adulthood and Aging. In Resnick B, Gwyther LP, \& Roberto, KA.. Resilience in Aging: Cocepts, Research, and Outcomes (163-180). New York: Springer Science+Bussiness Media. Doi: 10.1007/978-1-4419-0232-0_11. 
Fetzer Institute. (1999). Brief Multidimensional Measures of Religiousness/Spirituality. Available: http://www.fetzer.org/images/stories/pdf/MultidimensionalBooklet Ghorbani, N., Watson, P. J., Framaz, A. G., Morris, R. J., \& Hood, R. W. (2000). Muslim Attitudes Towards Religion scale: Factors, validity and complexity of relationships with mental health in Iran. Mental Health, Religion and Culture, 3, 125-132.

Goldstein, S \& Brooks, R. B. (2005). Why Study Resilience?. In Goldstein, S., \& Brooks, R. B. (ed). Handbook of Resilience in Children Issues in Clinical Child Psychology (3-15). New York: Springer.

Kasdi, Abdurahman, .(2003). Integritas Agama \& Ilmu Umum.Jakarta : UIN Press.

Khoshaba, D. M. \& Maddi, S. R. (1999). Early Experiences ini Hardiness Development. Consulting Psychology Journal: Practice and Research, Vol. 51, No. 2, 106-116.

Krauss, S. E., Noah, S. M., Juhari, R., Manap, J. M., Mastor, K. A., Kassan, H., \& Mahmood, A. (2006). Exploring Regional Differences In Religiosity Among Muslim Youth In Malaysia. Review Of Religious Research, Volume 47:3, Pages 238-252

Krause, N. (1999). Religious Support. . In Brief Multidimensional Measures of Religiousness/Spirituality (19-24). Fetzer Institute. Available: http://www.fetzer.org/images/stories/pdf/MultidimensionalBooklet Kumpfer, K. L. (1999). Factors and Processess Contributing to Resilience: The Resilience Framework .In Glantz \& Johnson (ed). Resilience and Development: Positive Life Adaptation (179-215).New York: Kluwer Academic / Plenum Publishers

Maddi, S. R. (2006). Hardiness: The Courage to Be Resilient . In Thomas, J. C., Segal, D. L. Comprehensive Handbook of Personality and Psychopathology: Personality and Everyday Functioning. Volume 1, (306321). New York. John Wiley and Sons. Inc.

Maddi, S. R. (1999). The Personality Construct of Hardiness: Effects on Experiencing, Coping, and Strain. Consulting Psychology Journal: Practice and Research, Vol. 51, No. 2, 83-94

Maddi S. R., Brow, M., Khoshaba, D.M., \& Vaitkus, M., (2006). Relationship of Hardiness and Religiousness to Depression and Anger. Consulting Psychology Journal: Practice and Research, Vol. 58, No. 3, 148-161. DOI: 10.1037/1065-9293.58.3.148

Maddi, S. R. \& Hightower, M. (1999) Hardiness and Optimism as Expressed in Coping Patterns. Consulting Psychology Journal: Practice and Research, Vol. 51, No. 2, 95-105

Maddi, S. R., Kahn, S., \& Maddi, K. L. (1998). The Effectiveness of Hardiness Training. Consulting Psychology Journal: Practice and Research, Vol. 50, No. 2, 78-86. 
Maddi, S. R., Khoshaba, D. M. \& Pammenter, A. (1999). The Hard Organization Success by Turning Change to Advantage. Consulting Psychology Journal: Practice and Research, Vol. 51, No. 2,117-124.

Marchant, D. C., Polman, R. C. J., Clough, P. J., Jackson, J. G., Levy, A. R., \& Nicholls, A. R. (2009). Mental Taughness: Managerial and Age of Difference. Journal of Managerial Psychology, Vol. 24, No. 5, pp. 428437. Doi: $10.1108 / 02683940910959753$.

Nashori, F dan Mucharram, J. (2002). Mengembangkan Kreatifitas Dalam Psikologi Islam. Yogyakarta : Menara Kudus.

Scheier, M. F., \& Carver, C. S. (1985) Optimism, coping, and health: Assessment and implications of generalized outcome expectancies. Health Psychology, 4(3), 219-247.

Shihab,Quraish. (2000). Tafsir Al-Mishbah". Jakarta. Lentera Hati

Smith, B. W., Dalen, J., Wiggins, K., Tooley, E., Christopher, P. \& Bernard, J. (2008). The Brief Resilience Scale: Assesing the ability to Bounce Back. International Journal Of Behavioral Medicine, 15, 194-200. Doi:10.1080/10705500802222972.

Ong, A. D., Bergeman, C.S., \& Boker, My. (2009). Resilience Comes of Age: Defining Features in Later Adulthood. Journal of Personality, 77 (6), 1778-1799. Doi:10.1111/j.1467-6494.2009.00600.x

Zhang, L. \& Wong, Y. (2011). Hardiness and Thinking Styles:Implications for Higher Education. Journal of Cognitive Education and Psychology Volume 10, Number 3. pp:294-307.Doi:10.1891/1945-8959.10.3.294. 